\section{What Do We Do With Applied Research?}

\author{
Richard W. Waterman, University of New Mexico \\ B. Dan Wood, Texas A\&M University
}

One of the most persistent criticisms of the behavioral sciences is that academics are only interested in developing theory for its own sake (e.g., see Ricci 1984). According to this argument, the development of social science theory provides society with few practical benefits. It survives only because it serves the needs of the academic community, providing fertile publishing ground for scholars to formulate, criticize, revise, reformulate, and debunk various theories. Critics view theory building as comparable to a dog chasing its tail. One can identify a great deal of activity, but there is little practical pay off.

We believe that this pernicious view of theory building has evolved because applied proposals for policy change that would demonstrate the value of social science theory are not generally published in mainstream journals. Mainstream journals identify theories about the nature of important governmental and societal problems. Often these theories provide the basis for remedial solutions that can be formulated as policy proposals. However, once theory is framed in an applied form, scholars generally consider it as inappropriate for publication in mainstream social science journals. Social scientists themselves have created the impression that theory is only formulated for its own sake.

In this article we ask what we believe is a fundamental question for the political science discipline:

"What does one do with applied research?" A satisfactory answer to this question would demonstrate the practical utility of social science theory-or what Lindblom and Cohen (1979) have called "usable knowledge." We illustrate our argument by presenting an example of an applied policy proposal that flows naturally from the last 40 years of the development of bureaucratic theory.

\section{The Accountability Problem and Bureaucratic Theory}

Citizens, public officials, and scholars alike have often promoted the normative goal of bureaucratic accountability-that is, bureaucrats should be responsible for their actions to the public and its elected institutions. In advancing this goal, scholars have often identified a factor that undermines political control by elected officials, namely, that bureaucrats have an information advantage over the public, members of Congress, and the president.

Because of their location within the bureaucracy and their propinquity to the policy process, bureaucrats become experts in a variety of narrow areas. And because they serve for life, rather than a limited electoral period, bureaucrats can wait out efforts at change to produce a longer-term effect than elected officials. Thus, bureaucrats have myriad opportunities to advance their own interests over those of the public at large.

The literature on the need for bureaucratic accountability is extensive. For over two decades an ideologically diverse group of scholars and political pundits such as Huntington (1952), Bernstein (1955), Kolko (1963), Cater (1964), Freeman (1965), Fellmeth (1970), and Stigler (1975) argued that bureaucrats, interest groups, and relevant congressional committees enter into an elitist "iron triangle" relationship, thus promoting their own special interests over the public interest. Bureaucrats and their agencies are essentially "captives" of these special interests. This literature identified the strategic location of bureaucrats and their information advantages as critical factors constraining attempts at bureaucratic accountability (Niskanen 1971). Furthermore, control by elected officials was assumed to be virtually nonexistent. The president and Congress (rather than just its individual committees) were considered to be out of the policy loop. And, since the courts rarely questioned the integrity of agency decisions, the judicial branch was also considered to be of little importance in promoting bureaucratic accountability.

During the 1960s scholars such as McConnell (1966), Lowi (1969), Redford (1969), and Rourke (1969) advanced the argument against bureaucracy another step. They asserted that in a democratic society, policy should be established by elected officials, rather than by nonelected bureaucrats. They also argued that when the nonelected denizens of bureaucracy assume this policymaking role, the constitutional system is subverted and democracy itself is imperiled. In order to preserve democracy, these scholars argued that bureaucracy must be made accountable to legal standards and to the will of elected officials.

Again, as with the iron triangle and capture theorists, these scholars identified the strategic advantages of bureaucrats as part of the problem. Issue expertise provides bureaucrats with policy advantages over elected officials. To remedy this problem it was recommended that Congress should enact clear, consistent, and unambiguous legislation, and that it should be more vigorous in its oversight of the bureaucracy. The courts were also urged to play a more active role in constraining bureaucratic attempts to exceed the letter of the law.

While these reform proposals had merit, they were also unrealistic. For example, since bargaining and compromise are endemic to the legislative process it is highly unlikely that unambiguous legislation will be enacted 
on a regular basis. Furthermore, since existing monitoring capabilities were identified as part of the problem, there was little reason to expect that congressional oversight would become more vigorous in the future. Therefore, while identifying an important problem, these scholars provided only a token remedy for the problem of bureaucratic accountability.

During the 1980 s a new literature on the bureaucracy developed. Derived from the economic theory of agency, it addressed many of the same concerns identified by earlier scholars (Bendor and Moe 1985, 1986; Moe 1982, 1985; Scholz and Wei 1986; Scholz, Twombly and Headrick 1991; Wood 1988; Wood and Waterman 1991a). A normative assumption of this literature was that bureaucrats should be held accountable to elected officials. Agency theory also identified what it called the information asymmetry problem as the primary factor undermining consistent political control of the bureaucracy. As with the previous literature on bureaucracy, oversight or monitoring was identified as a critical link between the realization of a principal's objectives and implementation by the bureaucracy. Monitoring was deemed important for two familiar reasons. First, the policy objectives of principals and agents will often diverge. Second, bureaucratic agents have a considerable information advantage over principals. Taken together, these two factors suggest that agents have both the motive and the means to promote self-interested objectives. Effective monitoring is vital because it provides the mechanism for offsetting information asymmetries between elected principals and bureaucratic agents.

Like earlier scholars, agency theorists identified the need for an effective monitoring mechanism. However, they too left unanswered the question of how monitoring could be made more effective. This failure to identify an effective monitoring mechanism is particularly important, since institutional scholars consistently argued that existing oversight capabilities are inadequate (Scher 1960; Fenno 1966; Bibby and Davidson 1972; Ogul 1976; Dodd and
Schott 1979; Fiorina 1981; Sundquist 1981; Smith and Deering 1984). ${ }^{1}$

Why are existing oversight capabilities inadequate? When Congress and the president attempt to monitor the bureaucracy they seek answers to specific questions. For example, they want to know whether a particular bureaucratic unit is performing in a manner consistent with existing legal standards. Is bureaucratic performance efficient and effective? Is it consistent with constituency needs? Have significant changes recently occurred in the level or substance of bureaucratic outputs, and if so, what specific stimulus caused the changes? Most important, they want to know whether bureaucratic performance is consistent with their own preferences.

For a variety of reasons, traditional oversight mechanisms have had a limited ability to provide reliable answers to these questions. First, because traditional oversight is conducted only sporadically, it cannot provide continuous answers to these questions over time. Even if answers are provided at one selected point in time, there is no guarantee that similar questions will even be asked at any future point in time. This is an important constraint since continuous oversight increases the probability that bureaucratic shirking will be detected. In fact, sporadic oversight may actually be an inducement for bureaucrats to engage in strategic behavior, since the probability of detection is limited.

A second problem with existing oversight is that elected institutions generally lack independent sources of information on bureaucracies. Instead, they frequently depend on information provided by the bureaucracy or other interested parties. Yet, bureaucrats will often have a clear incentive to mislead their political overseers. By practicing deception they can derive certain benefits that would not otherwise be possible (e.g., slack resources, increased discretion, their preferred outcomes). In order for political institutions to effectively monitor the bureaucracy, then, they must have access to independent information.

A third limitation of traditional oversight is that elected institutions lack a systematic method for evaluating the information they do receive from the bureaucracy. This constraint is critical because even when bureaucrats provide an honest appraisal of their agency's activities, they may be intentionally deceptive, mistaken, or important differences of opinion between experts may emerge. Without an objective evaluation criterion, elected institutions cannot evaluate conflicting claims or identify erroneous testimony.

What these three factors suggest, then, is that the best we can expect from existing oversight is to provide some answers, to some of the above questions, some of the time. However, due to the lack of systematic monitoring, bureaucratic accountability will be limited. A monitoring system capable of providing continuous oversight, independent information, and an objective evaluation criterion is therefore needed.

A careful reading of recent published research suggests that such a system could be available with only minor changes in government. In an earlier work we analyzed outputs from seven different federal bureaucracies with widely diverse organizational structures (Wood and Wateman 1991a). The goal of that study was to determine the "scope and mechanisms of political control" of the bureaucracy, a long debated theoretical question. However, the methodology used there, which we called "policy monitoring," also presented some practical possibilities for continuously and systematically monitoring the behavior of bureaucracy.

\section{A Demonstration of Policy Monitoring: The Deregulation and (Covert) Reregulation of the Trucking Industry}

The first stage of policy monitoring involves analyzing qualitative evidence to formulate testable hypotheses on bureaucratic performance through the period of interest. Here it is crucial to explore the unique historical context of the bureaucracy, as well as to identify stimuli relevant to bureaucratic accountability. Among the factors to be considered are the timing of political appointments, changes in budgetary allocations, bureaucratic reorganizations, the enactment of new legislation, and, 
more generally, the preferences of democratic institutions for particular bureaucratic outputs. Critical events (e.g., like the accident at Three Mile Island) and internal bureaucratic stimuli (e.g., temporary wild-eyed bureaucratic zealotry) should also be identified and controlled for in subsequent statistical analyses.

The Interstate Commerce Commission was intentionally designed to limit top down political control. Established on February 4, 1887, to regulate railroads involved in interstate transportation, Congress initially established the agency within the Interior Department. They soon reestablished it as an independent regulatory commission following the election of President Benjamin Harrison, a strong supporter of railroad interests. In doing so, Congress's clear intent was to limit presidential influence over commission activities. While presidents were granted authority to appoint the commission's members, they were not delegated authority to remove them from office. In addition, until 1969 presidents did not have the authority to designate the commission's chairman (Waterman 1989: 85).

In 1935 Congress passed the Motor Carrier Act, thus expanding the ICC's focus to include regulation of the trucking industry. Enacted at the peak of the Great Depression, the legislation was explicitly designed to restrict market entry and protect existing carriers from excessive competition. The law specified that in order for an operating certificate to be issued, a new prospective carrier must demonstrate that it was both fit and able to provide the proposed service. Applicants also had to prove that the service would satisfy a "public need," meaning that no other existing carrier could provide the same service. Operating under the provisions of the 1935 act, over the next 40 years the ICC issued only limited numbers of new operating certificates, despite the fact that the depression had long ago ended and more certificates would have provided greater public benefit through a larger choice of carriers and lower market prices.

The ICC was from 1935 to 1977 a quintessential example of what scholars of government regulation have called regulatory "capture" (e.g., Huntington 1952; Stigler 1975; Moore 1978). However, with the Carter administration an effort was begun to deregulate the transportation industry. In accordance with these goals, President Carter appointed A. Daniel O'Neal and, later, Darius Gaskins to chair the commission. These appointees initiated administrative reforms intended to liberalize ICC procedures for issuing new operating certificates. The administration also proposed legislation that would make the changes permanent. On July 1, 1980, the president signed into law a new Motor Carrier Act, which codified many of the ICC's earlier administrative reforms.

The Motor Carrier Act of 1980 represented a major break with past legislative intent by greatly easing restrictions on entry to the protected market. However, the legislation represented a "fragile compromise" since it did not remove either the fitness or public need provisions delineated in the original 1935 act. These provisions provided a potential mechanism for reregulating the trucking industry. So long as Carter and his ICC chairmen were in office, entry provisions could be liberally interpreted. However, this situation would soon change with the Reagan administration.

Ronald Reagan campaigned for president in 1980 as an economic deregulator. However, he had also been endorsed by the Teamsters Union, a vociferous opponent of deregulation because it encouraged fierce competition within the trucking industry and reduced benefits from a protected market. On June 16, 1981, President Reagan appointed Reese Taylor as the ICC's new chairman, a man reputed to have close ties with the Teamsters.

In public appearances Taylor quickly distanced himself from the Carter style of deregulation. Testifying before Congress he admitted to being neither a "regulator nor a deregulator"' (U.S. Congress 1982: 3). $\mathrm{He}$ also defended the existing fitness and public needs provisions of the 1935 and 1980 Motor Carrier Acts (U.S. Congress 1981: 70, 80-81) and advocated a slower path toward deregulation (ICC 1982: 4). Once in office Taylor also removed or transferred (to positions of lesser authority) individuals who had previously supported deregulation.

The year following his appointment, congressional committee members heard testimony that Taylor's ICC had abandoned the goal of deregulation. Taylor's critics argued that the ICC was issuing fewer operating certificates, and, as a result, the trucking industry was becoming less competitive. The stimulus for this change, critics argued, was political, an alleged reward to the Teamsters for support in the 1980 campaign. Taylor and other Reagan administration officials were quick to agree that the number of certificates issued by the ICC had declined during his first year in office. However, they did not agree with the critic's contention that the stimulus for the change was political. Rather, they argued that market forces encouraged the reduction in the number of operating certificates issued. According to their argument, only so many trucking firms could profitably provide service at any one time. As the trucking market became saturated, it was natural that fewer companies would seek new operating authority.

Traditional oversight identified two rival hypotheses for the cause of trucking reregulation by the ICC. One hypothesis suggested that a political factor (i.e., the Taylor appointment) was the stimulus for change. The second hypothesis was that natural market forces (i.e., the invisible hand of competition) had limited the demand for new certificates. Yet, congressional oversight committees were unable to conclusively determine which, if either, hypothesis was correct.

A determination between the two hypotheses was important because the committees had expressed clear views on how they intended the 1980 Motor Carrier Act to be implemented. At Taylor's confirmation hearing Senator Howard Cannon (D-NV) explicitly warned the nominee that the Senate committee would be watching "very closely to insure that transportation legislation is implemented expeditiously." Cannon also warned that "there are strong views on this committee in favor of competition. . ." (U.S. Congress 
FIGURE 1

Interstate Commerce Commission Operating Certificates Issued

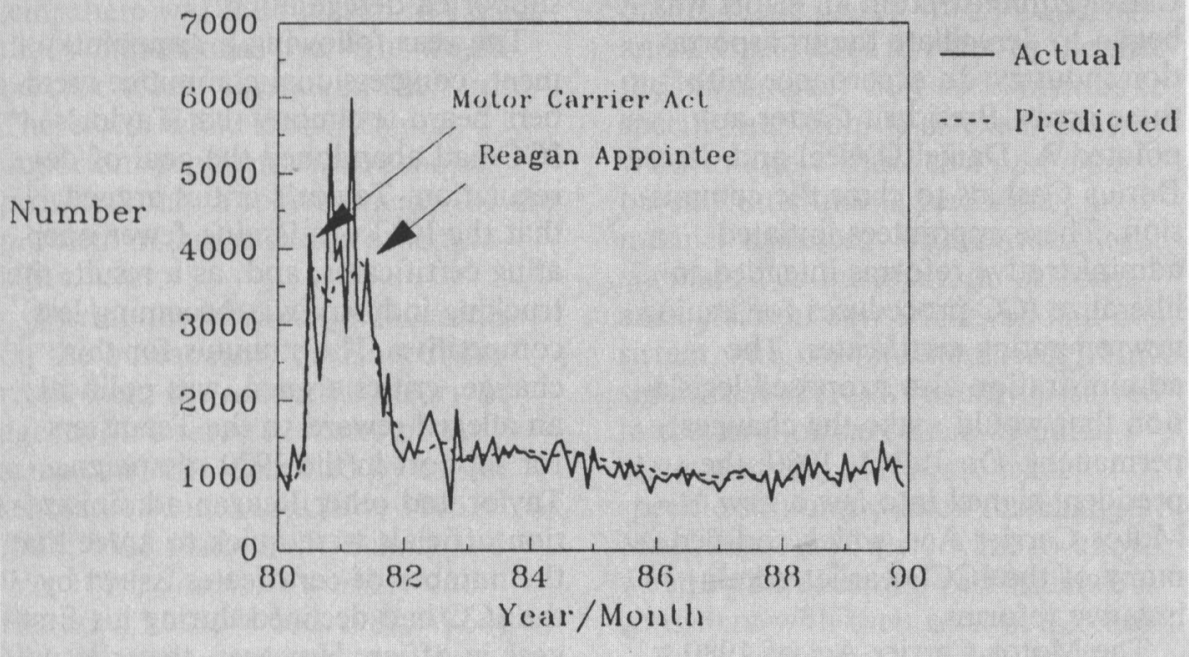

1981: 2). Despite these warnings, and five years of intensive hearings, the relevant House and Senate committees were unable to determine the stimulus for change in the ICC's regulatory behavior, and bureaucratic accountability could not be enforced.

Thus, the first stage of policy monitoring, an analysis of qualitative evidence, provides us with the same two hypotheses derived by traditional oversight on the causes of trucking reregulation. The task, then, is to do what traditional oversight could not do, namely, determine the precise stimulus causing the change in ICC's regulatory behavior. To accomplish this objective we move to the second stage of policy monitoring, the collection of qualitative data on agency outputs.

We obtained monthly data on ICC regulation of the trucking industry with a Freedom of Information Act request; however, we propose below an institutionalized reporting system that would make such data regularly available to policy analysts without such efforts. Ideally, policy monitoring should involve analysis of multiple measures having sufficient temporal resolution to identify specific causal mechanisms. ${ }^{2}$ Due to space limitations we consider here only one measure of ICC outputs, the number of operating certificates issued monthly from January 1980 through October 1990.

The third stage of policy monitoring involves an analysis of agency outputs using an objective evaluation criterion. For this example we employed interrupted time series methods (Box and Jenkins 1976; Box and Tiao 1975). Statistical results of the analysis are in Table 1 . Graphs

\section{TABLE 1}

Interstate Commerce Commission Operating Certificates Issued

\begin{tabular}{lccr}
\hline Variable* & Parameter & Estimate & t-statistic \\
\hline Motor Carrier Act & $\omega_{01}$ & 1.15 & 9.85 \\
Reagan Appointment & $\omega_{02}$ & -0.26 & -4.06 \\
& $\delta_{12}$ & 0.76 & 11.49 \\
Moving Average & $\Theta_{1}$ & 0.85 & 16.29 \\
\hline Measures of Fit & & & \\
Residual Mean Square (Noise Only) & & 0.060 & \\
Residual Mean Square (Full Model) & & 0.039 Change $=54 \%$ \\
Autocorrelation of Residuals & $\mathrm{Q}=33.71$ with 23 D.F. \\
\hline
\end{tabular}

Note: The series was logged and differenced to produce variance stationarity. The intervention series were step inputs. All model parameters were significant at the 0.05 level or less.

of the actual data and model predictions from the analysis are in Figure 1.

Concerning the passage of the Motor Carrier Act of 1980, the model shows that the new legislation accomplished its deregulatory purpose. Beginning in the same month the law was signed there was an abrupt increase in the number of operating certificates issued. The magnitude of the increase was about $300 \%$ from the pre-intervention equilibrium level. ${ }^{3}$ For the next 12 months the number of certificates issued in a single month ranged from a low of just over 2,000 to a high of about 6,000 ; this compared to a preintervention equilibrium level of about 1,000 certificates issued per month. Thus, as Congress had intended, the Motor Carrier Act of 1980 promoted increased competition for the trucking industry.

Concerning the reasons for reregulation, traditional congressional oversight was incapable of evaluating the merits of the two rival hypotheses discussed above. However, the analysis presented in Table 1 and Figure 1 demonstrates clearly which hypothesis was correct. According to the argument advocated by Reese Taylor and the Reagan administration, the motor carrier market could not possibly sustain the influx of new motor carriers. Eventually, market forces would force a reduction in the number of certificates issued. If this argument was correct, then we would expect to see a gradual decline beginning some time after the new legislation was enacted. However, what we observe instead is that the decline in the number of certificates issued by the ICC was abrupt, corresponding exactly with Reagan's appointment of Reese Taylor to chair the ICC.

The statistical analysis shows that in the month following Taylor's appointment there was a $28 \%$ decline in the number of operating certificates issued. Further, over the next several months there was a continued steady decline until a new equilibrium was reached, some $66 \%$ below the level established following the passage of the Motor Carrier Act of 1980. Of equal importance, at no point following Taylor's appointment did the number of operating certifi- 
cates issued ever equal or exceed the level that had existed prior to his appointment. Ronald Reagan's appointment of Reese Taylor to chair the ICC was the stimulus for a substantial and immediate reduction in the number of certificates issued by the ICC. ${ }^{4}$

Thus, we have demonstrated that a political stimulus, not market forces, produced the change in ICC's regulatory behavior. This knowledge is important for two reasons. First, it demonstrates the extent to which the ICC was unresponsive to past legislative intent and current congressional preferences. Despite congressional warnings, Taylor did not enforce the intent of the 1980 legislation. Had Congress had the capacity to show this during the early 1980 s, then it could have taken remedial action.

Second, the ICC case is also interesting for its substantive implications for the Reagan presidency. The Reagan presidency is widely viewed as one emphasizing economic deregulation. Yet, the ICC case shows that Ronald Reagan was actually a reregulatory president when there was some political benefit to be gained. The case of the ICC represents a second regulatory face of Ronald Reagan, one in which he was actually an advocate of increased, not decreased, government regulation.

\section{Policy Recommendations}

As "capture," "iron triangle," traditional bureaucratic, and agency theory scholars have argued, an effective monitoring mechanism is required to enforce bureaucratic accountability. We have demonstrated how techniques recently used for testing bureaucratic theories can achieve this purpose. Policy monitoring, when fully implemented, would provide for continuous and systematic oversight of bureaucratic outputs over time. It would provide elected institutions with an independent source of information. It would also provide explicitly objective evaluation criteria for analyzing agency outputs, serving as an important supplement to existing oversight mechanisms.

We therefore make the following recommendations:

1. A central tracking agency should be established for the purpose of collecting, storing, and analyzing data on agency outputs over time. The tracking agency should be nonpartisan, along the lines of a General Accounting Office or Congressional Budget Office. We also recommend that the agency should be located within the legislative branch.

2. Congress should mandate that each federal agency, including the independent regulatory commissions, provide detailed data on core technology outputs to the central tracking agency. In making this recommendation we recognize that some agency outputs will not be amenable to an interrupted time series analysis. The central tracking agency should therefore select appropriate evaluation criteria for each type of bureaucratic output.

3. Wherever possible data should be provided to the tracking agency at sufficiently frequent time intervals. The analysis of the Interstate Commerce Commission demonstrated how an analysis of monthly data can establish causal relations between a particular stimulus and a bureaucratic response. As the case of the ICC demonstrates, it can also provide an estimate of the magnitude, direction, and duration of changes in agency outputs, as well as identifying when changes occurred.

4. Policy analysts should regularly analyze agency outputs using a variety of different statistical techniques, including time series methods, to evaluate bureaucratic responsiveness. Only through the use of objective evaluation criteria can elected officials be sure that the information they receive is reliable and unbiased.

5. The results of policy analysis should be presented to the president, the relevant bureaucratic unit, the relevant oversight committees, the media, and upon request to the public. Results should also be made publicly available at regular intervals (not less than annual). The goal of bureaucratic accountability can best be served by making sure the results derived through policy monitoring are available to a broad audience at regular intervals.

In offering these five recommendations we do not mean to suggest that policy monitoring is a panacea. Some agency outputs may be difficult to quantify or to analyze. Bureaucratic bean counting and other threats to validity may raise questions about the findings (e.g., see Gormley 1989). On a political level, some officials may not appreciate public scrutiny of their activities. We recognize that policy monitoring, like existing oversight mechanisms, will have its limitations. While it is not a cure-all, we believe it is a positive step toward a more rigorous system for overseeing the bureaucracy.

\section{Conclusions}

Our analysis of the bureaucratic literature over the past 40 years demonstrates that scholars have long promoted the goal of bureaucratic accountability. Our extrapolation of this literature, along with a demonstration of useful empirical techniques, shows that a mechanism for promoting bureaucratic accountability is available with only minor changes in government. Thus, theory based social science research does sometimes offer practical solutions to real world problems.

The criticism that social science theory operates only for its own sake is pernicious, but understandable, given the present attitudes toward publishing applied research in mainstream social science journals. While theory often provides a basis for practical solutions to important governmental and societal problems, these research solutions are seldom presented in these professional outlets. As a result, the practical pay off that derives from social science theory is lost-creating the impression that it is only a process of theory for its own sake.

The obstacle to broader understanding of this point is not a limitation inherent in social science theory, but rather in the proclivity of the discipline toward not publishing applied proposals for policy change in mainstream social science journals. Of course, there is ample precedent for publishing applied work in the top journals of other disciplines: biology, chemistry, physics, engineering, and medical journals all contain such work. The maturation of social science requires that we be as committed to propagating "usable knowledge" as to continuing the in- 
tellectual discourse. Otherwise, we undervalue the true worth of social science theory building.

\section{Notes}

1. This is not to suggest that existing means of congressional oversight have not been capable, or are not capable of exerting some influence. Wood and Waterman (1991b), Aberbach (1990), McCubbins and Schwartz (1984), and Weingast and Moran (1983) have each demonstrated that Congress is capable of exerting influence over a variety of agencies. However, even these studies have not identified a continuous and systematic means for congressional oversight, which is what we advocate here.

2. One obvious question is whether data of the sort required for "policy monitoring" would impose an additional paperwork burden on federal bureaucracies. On this, we should point out that most federal bureaucracies have already adopted routine procedures for collecting and storing output data for internal use. In fact, in our own research we have obtained data from nine different federal agencies with sufficient temporal resolution to do the type of analysis reported here. Other scholars have also obtained data from a variety of other agencies at both the federal and state level. Thus, while the transition to a federal tracking system would involve some complications, much of the data on agency outputs, are already being kept.

3. A zero order transfer function was used here with no lag. The data were logged to assure efficient statistical estimates due to variance nonstationarity.

4. Having identified the critical role that the Taylor appointment played in the reregulation of the trucking industry, policy monitoring's fourth stage required that we conduct follow-up interviews and search additional qualitative sources to determine if any other explanations could be found that would better explain the changes which occurred at the ICC. Other potential explanations, such as the possibility of a budget cut or sudden economic shock were also considered and eliminated.

\section{References}

Aberbach, Joel D. 1990. Keeping a Watchful Eye: The Politics of Congressional Oversight. Washington, DC: Brookings Institution.

Bernstein, Marver H. 1955. Regulating Business by Independent Commission. Princeton: Princeton University Press.

Bendor, Jonathan and Terry Moe. 1985. "An Adaptive Model of Bureaucratic Politics.' American Political Science Review 79: 755-74.

Bendor, Jonathan and Terry Moe. 1986. "Agency Control, Committee Capture, and the Dynamics of Institutional Politics." American Political Science Review 80: 1187-1208.

Bibby, John F. and Roger H. Davidson. 1972. On Capitol Hill. Hinsdale, IL: Dryden Press.
Box, G. E. P. and G. M. Jenkins. 1976. Time Series Analysis: Forecasting and Control. San Francisco: Holden-Day, Inc.

Box, G. E. P. and G. C. Tiao. 1975. "Intervention Analysis with Applications to Economic and Environmental Problems." Journal of the American Statistical Association 70: 70-79.

Cater, Douglass. 1964. Power in Washington. New York: Random House.

Dodd, Lawrence and Richard Schott. 1979. Congress and the Administrative State. New York: Wiley and Sons.

Fellmeth, Robert. 1970. The Interstate Com merce Omission: The Public Interest and the ICC. New York: Grossman.

Fenno, Richard F. Jr. 1966. The Power of the Purse: Appropriations Politics in Congress. Boston: Little, Brown and Co.

Fiorina, Morris. 1981. "Congressional Control of the Bureaucracy: A Mismatch of Incentives and Capabilities." In Congress Reconsidered, ed. Lawrence Dodd and Bruce Oppenheimer. Washington, DC: Congressional Quarterly Press.

Freeman, J. Leiper. 1965. The Political Process: Executive-Bureau-Legislative Committee Relations. New York: Random House.

Gormley, William T. 1989. Taming the Bureaucracy: Muscles, Prayers, and Other Strategies. Princeton, NJ: Princeton University Press.

Huntington, Samuel P. 1952. "The Marasmus of the ICC: The Commission, the Railroads, and the Public Interest." Yale Law Journal 61: 467-509.

Kolko, Gabriel. 1963. The Triumph of Conservatism: $A$ Reinterpretation of American History, 1900-1916. New York: Free Press.

Lindblom, Charles E. and David K. Cohen. 1979. Usable Knowledge: Social Science and Social Problem Solving. New Haven: Yale University Press.

Lowi, Theodore J. 1969. The End of Liberalism. New York: W.W. Norton.

McConnell, Grant. 1966. Private Power and American Democracy. New York: Vintage Press.

McCubbins, Mathew D. and Thomas Schwartz. 1984. "Congressional Oversight Overlooked: Police Patrols vs. Fire Alarms." American Journal of Political Science 28: 165-69.

Moe, Terry M. 1982. "Regulatory Performance and Presidential Administration." American Journal of Political Science 26: 197-224.

Moe, Terry M. 1985. "Control and Feedback in Economic Regulation: The Case of the NLRB." American Political Science Review 79: 1094-1116.

Moore, Thomas Gale. 1978. "The Beneficiaries of Trucking Regulation." Journal of Law and Economics (Oct.).

Moore, Thomas Gale. 1982. "RegulationThe First Year: Transportation." Regulation (Jan./Feb.): 27-29.

Niskanen, William A. 1971. Bureaucracy and Representative Government. Chicago: Aldine Press.

Ogul, Morris. 1976. Congress Oversees the Bureaucracy. Pittsburgh: University of Pittsburgh Press.

Redford, Emmette. 1969. Democracy and the
Administrative State. New York: Oxford University Press.

Ricci, D. 1984. The Tragedy of Political Science. New Haven: Yale University Press.

Rourke, Francis. 1969. Bureaucracy, Politics, and Public Policy. Boston: Little, Brown and Co.

Scher, Seymour. 1960. "Congressional Committee Members as Independent Agency Overseers: A Case Study." American Political Science Review 54: 911-20.

Scholz, John T, and Feng-heng Wei. 1986. "Regulatory Enforcement in a Federalist System." American Political Science Review 80: 1249-70.

Scholz, John T., J. Twombly, and B. Headrick. 1991. "Street Level Political Controls Over Federal Bureaucracy." Ameri can Political Science Review 85: 829-50.

Smith, Steven S. and Christopher J. Deering. 1984. Committees in Congress. Washington, DC: Congressional Quarterly Press.

Stigler, George J. 1975. The Citizen and the State: Essays on Regulation. Chicago: University of Chicago Press.

Sundquist, James. 1981. The Decline and Resurgence of Congress. Washington, DC: Brookings Institution.

U.S. Congress. 1981. Nomination-Chairman of the Interstate Commerce Commission. Hearings Before the Senate Committee on Commerce, Science, and Transportation.

U.S. Congress. 1982. Oversight-Motor Carrier Act of 1980. Hearings Before the House Public Works Committee.

Waterman, Richard W, 1989. Presidential Influence and the Administrative State. Knoxville, TN: University of Tennessee Press.

Weingast, Barry R. and Mark J. MOran. 1983. "Bureaucratic Discretion or Congressional Control: Regulatory Policymaking by the Federal Trade Commission." Journal of Political Economy 91: 765-800.

Wood, B. Dan. 1988. "Principals, Bureaucrats, and Responsiveness in Clear Air Enforcements." American Political Science Review 82: 213-34.

Wood, B. Dan. 1990. "Does Politics Make a Difference at the EEOC?" American Journal of Political Science 34: 503-30.

Wood, B. Dan. 1991. "Federalism and Policy Responsiveness: The Clean Air Case." Journal of Politics 53: 851-59.

Wood, B. Dan., and Richard W. Waterman. 1991a. "The Dynamics of Political Control of the Bureaucracy.' American Political Science Review 85: 801-28.

Wood, B. Dan, and Richard W. Waterman. 1991b. "The Dynamics of PoliticalBureaucratic Adaptation." Paper presented at the Annual Meeting of the American Political Science Association, Washington, DC.

\section{About the Authors}

Richard W. Waterman is assistant professor at the University of New Mexico. B. Dan Wood is an associate professor at Texas A\&M University. They have written several articles on bureaucracy in journals such as $A P S R$ and $A J P S$. 